\title{
US Unemployment Among Younger Adults And Recommendations To Improve Employment Sustainability
}

\author{
Orlando Rivero, D.B.A., Carlos Albizu University, USA
}

\begin{abstract}
The United States unemployment rate continues to be a focal point of discussion. Although in July 2012, the United States Bureau of Labor Statistics reported an $8.3 \%$ unemployment rate in America, this figure only reflects workers between the ages of 16 and older. With this being said, there is a segment of the population unrepresented within the totality of the United States unemployment rate reported. Younger workers between the ages of 16 to 24 years of age have sustained a much higher unemployment rate as compared to older workers. Unfortunately, $93 \%$ of these younger workers do not have a high school diploma and the majority of these workers were supporting families. The purpose of this article is to examine several components of the unemployment rate as it relates to younger workers between the ages of 16 to 24 years of age. Recommendations will be offered in an effort to improve employment sustainability among younger workers, which has been an issue that has been ignored for several years until recently.
\end{abstract}

Keywords: Unemployment among Younger Adults; Components of the Unemployment Rate; Employment Sustainability

\section{INTRODUCTION}

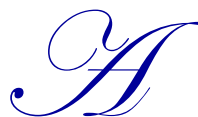
lthough the United States unemployment rate among workers remained constant for the period covering January 2012 - July 2012, there is still room for improvement. For example, younger workers' (between the ages of 16 to 24 years) unemployment rate was more than twice that of the national unemployment rate. Although federal aid has made a difference, there is still so much that could be accomplished through mentorship and educational initiatives. In this document, several components will be evaluated and recommendations will be made to improve the employment sustainability of young adults.

The United States unemployment rate continues to be a model used to determine the effects of unemployment within the economic system. The unemployment rate in 2009, ages, 16 years and older, reached an all-time high of $10 \%$ as compared to previous years. However, from January through July 2012, unemployment remained consistent at $8.3 \%$ (U.S. Labor \& Statistics, 2012). A recent study suggested that younger workers, between the ages of 16 to 24, sustained a higher unemployment rate between $19 \%$ and $33 \%$. Additionally, $93 \%$ of these younger workers had no high school diploma and the majority of them were supporting themselves or family members. Interestingly, young adults between the ages of 20 to 24 years old had earned a high school diploma of which 15\% had completed some college credits (U.S. Congress Joint Economic Committee, 2010).

According to the Bureau of Labor Statistics (2010), younger workers comprise 13\% of all employees, but were not evenly distributed across respective industries. Most younger workers (16 to 19 years of age) are employed within the hospitality industry, which constitutes $34 \%$ of the total workforce and the remaining are employed in the wholesale and retail trade, which makes up the remaining workforce totality. 

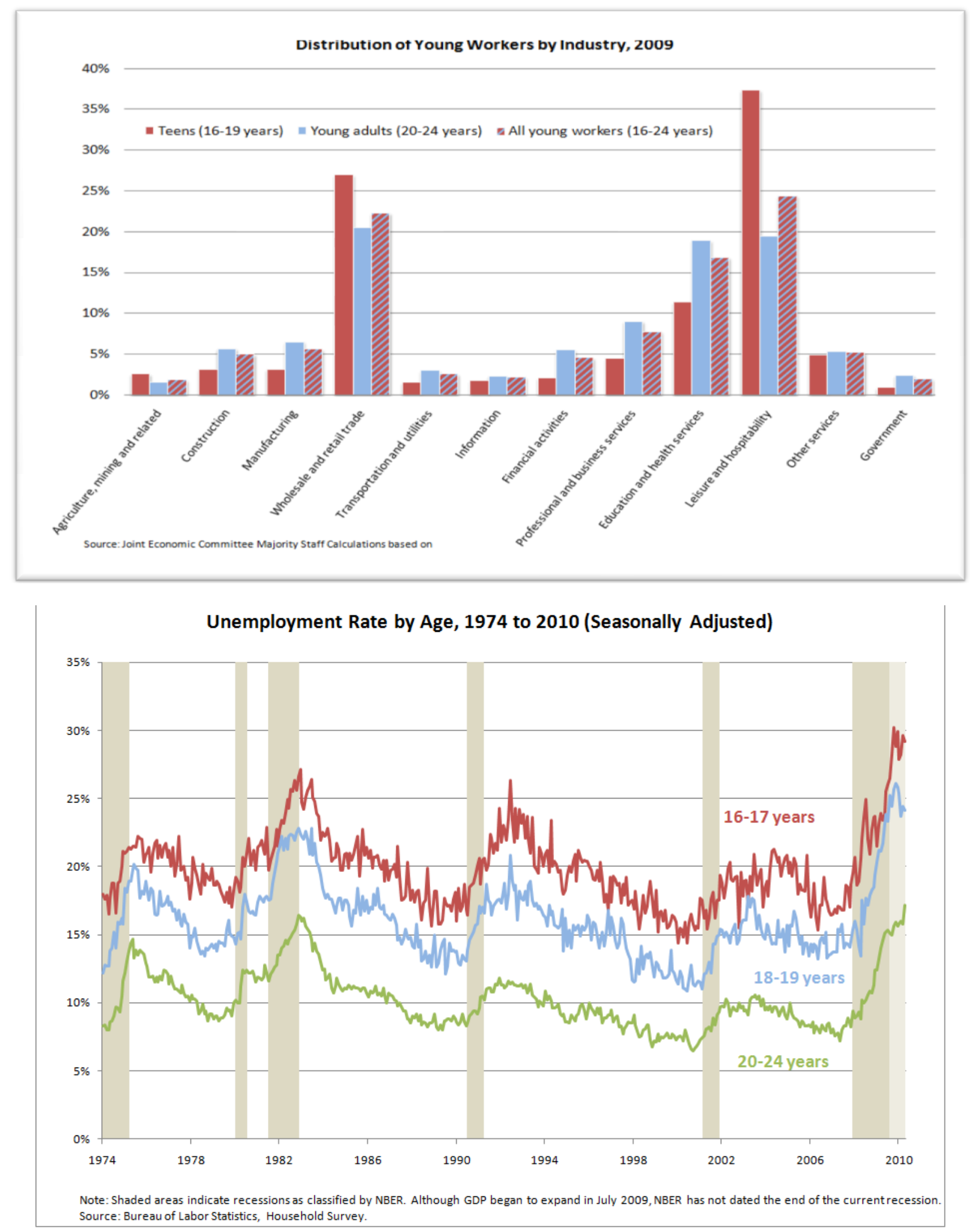
Historically, unemployment among young adults decreases when they complete additional education initiatives (high diploma/college degree). Interestingly, young adults only make up $1.2 \%$ of the labor force. The unemployment rate was lower for older adults (20 to 24 years old) at $24.1 \%$; which constituted $2.6 \%$ of the labor force. Not surprisingly, young adults in the labor market tend to be more educated than teens, with $90 \%$ having at least a high school diploma, and 15\% having earned a college degree (Bureau of Labor Statistics, 2010).

According to a study conducted by the Pew Research Center (2012), 54\% of Americans between the ages of 18 to 24 were employed, which is the lowest employment rate for this age group since 1948. Most alarming, though, is the sharp drop of $62 \%$ who were employed in 2007. The Pew study also revealed that a third of adults between the ages 18 to 34 , are returning to school to sharpen their skills to be equipped when the labor market bounces back. Also, a quarter have taken an unpaid job or have moved back in with parents and one in five has put off having a child or getting married due to economic concerns.

However, in 2012, the Bureau of Labor reported a drop of $24.7 \%$ in the unemployment rate among young adults (16 to 24 years of age). This could be attributable to the increase of federal aid that included the implementation of the Health Care and Education Affordability Reconciliation Act of 2010, which encompassed one of the largest investments to assist student aid in United States history. With the added benefit, there were changes to student financial aid, which included a new direct federal lending program (students attending a university/college are required to pay interest on student loans), adding savings to taxpayers in the long run. Other benefits included federal monies in the amount of $\$ 2.5$ billion to historically black colleges and universities. Also, an allocation of $\$ 2$ billion to community colleges through a competitive grant program that will help strengthen career training programs (H.R. $4872\left(111^{\text {th }}\right)$. 2010).

\section{RECOMMENDATIONS}

It is recommended that younger adults be mentored to pursue a career path of their interest, but primarily a career path in business. Pursuing a degree in business administration will prepare students for various management positions and enhance opportunities for career advancement in a wide range of specializations. Business administration curriculum provides graduates with business principles and practices learned in class so they can perform well in their chosen career path. Most importantly, business graduates are trained to think critically in order to solve business problems in the most effective manner, as well as having good communication skills to promote collaborative efforts within organizations.

According to a recent survey conducted by National Association of Colleges Employers (2012), employers will tend to hire a business graduate as opposed to non business degreed graduates. This same survey also revealed that a business degree ranks as the 'top' choice of individuals who are seeking a degree program. Although the unemployment rate has stabilized in certain parts of the country, there is still a surge of job applicants with unmatched skill sets, which puts them in a huge disadvantage when competing for employment opportunities on national and local levels.

According to the United States Department of Labor, the position Financial Examiner will have a job growth of $41 \%$ nationally (State of Florida, 32\%) by 2018 and will be ranked second as the fastest growing occupation in the nation. A Financial Examiner is a professional with the responsibility to enforce or ensure compliance with laws and regulations governing financial and securities institutions and financial and real estate transactions (United States Department of Labor Statistics, 2011 May). This term is loosely used to describe accountants who have the responsibilities, but not limited to examining, analyzing, and interpreting accounting records to prepare financial statements, etc. (Bureau of Labor Statistics. Office of Occupational Statistics and Employment Projections, 2012) 


\begin{tabular}{|c|c|c|c|}
\hline \multirow{2}{*}{ United States } & \multicolumn{2}{|c|}{ Employment } & \multirow{2}{*}{$\begin{array}{l}\text { Percent } \\
\text { Change }\end{array}$} \\
\hline & 2008 & 2018 & \\
\hline Financial examiners & 27,000 & 38,100 & $+41 \%$ \\
\hline \multirow{2}{*}{ Florida } & \multicolumn{2}{|c|}{ Employment } & \multirow{2}{*}{$\begin{array}{l}\text { Percent } \\
\text { Change }\end{array}$} \\
\hline & 2008 & 2018 & \\
\hline Financial examiners & 610 & 800 & $+32 \%$ \\
\hline
\end{tabular}

This same study also revealed that the position of Personal Financial Advisor is in high demand. It is ranked thirteenth as one of the fastest growing occupations in the nation. It is estimated that the said occupation will see a 30\% job increase nationally (State of Florida, 24\%) by 2018.

\begin{tabular}{|l|c|c|c|}
\hline \multirow{2}{*}{ United States } & \multicolumn{2}{|c|}{ Employment } & \multirow{2}{*}{$\begin{array}{c}\text { Percent } \\
\text { Change }\end{array}$} \\
\cline { 2 - 4 } & 2008 & 2018 & \\
\hline Personal financial advisors & 208,400 & 271,200 & $+30 \%$ \\
\hline \multirow{2}{*}{ Florida } & \multicolumn{2}{|c|}{ Employment } & \multirow{2}{*}{$\begin{array}{c}\text { Percent } \\
\text { Change }\end{array}$} \\
\cline { 2 - 3 } & 2008 & 2018 & $+24 \%$ \\
\hline Personal financial advisors & 19,450 & 24,100 & $+24 \%$ \\
\hline
\end{tabular}

Top 50 Fastest-Growing Occupations in the Nation

2008-2018

\begin{tabular}{lllll}
\hline & Top 50 & \multicolumn{3}{c}{$\mathbf{2 0 0 8 - 2 0 1 8}$} \\
1 & Biomedical engineer & $\underline{\text { Jobs }}$ & $\underline{\text { Jobs }}$ & \% chg \\
2 & Financial examiners & 16,100 & 27,600 & $72 \%$ \\
3 & Medical scientists, except epidemiologists & 27,000 & 38,100 & $41 \%$ \\
4 & Physician assistants & 109,400 & 153,600 & $40 \%$ \\
5 & Biochemists and biophysicists & 74,800 & 103,900 & $39 \%$ \\
6 & Athletic trainers & 23,200 & 31,900 & $37 \%$ \\
7 & Computer software engineers, applications & 16,400 & 22,400 & $37 \%$ \\
8 & Veterinarians & 514,800 & 689,900 & $34 \%$ \\
9 & Environmental engineers & 59,700 & 79,400 & $33 \%$ \\
10 & Computer software engineers, systems software & 54,300 & 70,900 & $31 \%$ \\
11 & Survey researchers & 394,800 & 515,000 & $30 \%$ \\
12 & Physical therapists & 23,400 & 30,500 & $30 \%$ \\
13 & Personal financial advisors & 185,500 & 241,700 & $30 \%$ \\
\hline
\end{tabular}

\section{CONCLUSION}

Although there have been plenty of positive changes to improve the unemployment rate among young adults, there is still room for improvement. The majority of young adults are employed in industries that are no longer in demand. Community outreach centers should be established by local government, with the assistance of Federal Aid, in order to educate and guide young adults to select a career path in demand. Similar mentorship programs have been established within the inner cities throughout America, but are more focused toward reducing violence, which has proven to be very successful (Harms, 2012). 
This writer does offer several recommendations to establish curriculum among young adults entering senior high school in an effort for them to be better prepared and competitive in the job market. They are as follows:

1. Establish a personal finance class curriculum to assist students with basic everyday finance needs.

2. Establish a career mentorship program to assist students in the selection of a career path of their choice and the importance of completing a college degree program from both a personal and income perspective.

3. Establish a basic economics course curriculum that will assist students in understanding the very basics of the United States Economy.

4. Institute partnership-driven initiatives among major corporations and federal/local/state government agencies to assist inner city social programs for under privileged students.

\section{AUTHOR INFORMATION}

Orlando Rivero is the Director, Business Department (School of Business) at Carlos Albizu University, USA. Dr. Rivero serves as the chief learning officer directing the administration, policies, integrity, program, and personnel of the instructional programs. He additionally provides leadership in areas of professional development for interdisciplinary faculty to ensure quality of academic programs. Dr. Rivero provides leadership and direction for all academically-related issues, including program and accreditation as well as instructional and curricular initiatives, to meet the changing needs of the community. Dr. Rivero is the vice-president of JDT Management Consultants in Clearwater, Florida, specializing in management, organization, strategy, international business, human resources, organizational development, and educational administration. E-mail: orivero01@yahoo.com

Prior to embarking into academia, Dr. Rivero also served in various leadership roles for 20 years with the local government. His experience within Miami-Dade County includes work within the following roles and departments: Administrator of Operations, Miami-Dade Police Department - Animal Services Unit, Budget Analyst, Miami Dade Corrections \& Rehabilitation Department, and Affirmative Action Administrator, Department of Business Development. During his tenure with Miami-Dade County, he was also the recipient of the 2004 National Association of Counties (NACO) Achievement Award for the implementation of several community-driven programs in Miami-Dade County, Florida.

He earned his Doctoral degree in Business from Argosy University and completed his Master of Public Administration degree at Nova Southeastern University. Dr. Rivero's primary research focus is on public Administration, leadership, management, and effective communication.

\section{REFERENCES}

1. Bureau of Labor Statistics, (2009). Bureau of labor statistics, payroll survey. Retrieved from website: http://www.bls.gov/ces/

2. Bureau of Labor Statistics. Office of Occupational Statistics and Employment Projections. (2012). Occupational profile. Financial examiners: Florida. Retrieved August12, 2012, from http://www.careerinfonet.org/occ rep.asp?printer=true\&next=occ rep\&Level=BAplus\&optstatus=101000 000\&jobfam $=13 \& \mathrm{id}=1 \&$ nodeid $=2 \&$ soccode $=132061 \&$ stfips $=12 \& \mathrm{x}=18 \& \mathrm{y}=8$

3. Harms, W. (2012, July 13). Study: Chicago counseling program reduces youth violence, improves school engagement. The University of Chicago. Retrieved August12, 2012, from http://news.uchicago.edu/article/2012/07/13/study-chicago-counseling-program-reduces-youth-violenceimproves-school-engagement

4. H.R. $4872\left(111^{\text {th }}\right)$ : Health care and education reconciliation act of 2010. (2010). GovTrack. Retrieved August12, 2012, from http://www.govtrack.us/congress/ bills/111/hr4872

5. National Association of Colleges Employers, (2012). Salaries climb for class of 2012 graduates. Retrieved August12, 2012, from website: http://www.naceweb.org/Press/Releases/Salaries_Climb_for_Class_of_2012_Graduates.aspx?referal=press room\&menuid $=273$ 
6. Pew Research Center. (2012, February 9). Young, underemployed and optimistic: Coming of age, slowly, in a tough economy. Retrieved August12, 2012, from http://www.pewsocialtrends.org/2012/02/09/youngunderemployed-and-optimistic/?src=prc-headline

7. United States Department of Labor. Bureau of Labor Statistics. (2011, May). Occupational employment and Wages, May 2011, 13-2061 financial examiners. Retrieved August12, 2012, from http://www.bls.gov/oes/current/oes132061.htm

8. U.S. Congress Joint Economic Committee. (2010, May). Understand the economy: Unemployment among young workers. Retrieved August12, 2012, from http://www.jec.senate.gov/public/?a=Files.Serve\&File_id=adaef80b-d1f3-479c-97e7-727f4c0d9ce6

9. United States Department of Labor, (2012). Retrieved from website: http://www.dol.gov/

10. United States Census Bureau, (2007). United States census bureau. Retrieved from United States Census Bureau website: http://www.census.gov/statab/ranks/rank25.html 